\title{
短 報〔Note〕
}

\section{クロロフィル蛍光を用いた現場植物プランクトンー次生産力測定法 の検討}

\author{
太田洋平・後藤直成・伴修平
}

\section{Estimation of in situ primary productivity using chlorophyll fluorescence technique in phytoplankton and its verification}

\author{
Yohei OTA, Naoshige GOTO, Syuhei BAN
}

\begin{abstract}
Primary production by phytoplankton is an important source of energy input to aquatic ecosystems, but its measurement is time-consuming and done infrequently using traditional methods. In this study, we adopted new method using a chlorophyll fluorescence ( $\mathrm{CF}$ ) technique, and continuously measured in situ primary productivity in phytoplankton assemblages at a central site in the north basin of Lake Biwa, Shiga Prefecture, Japan, from April to December, 2012. The accuracy of the CF technique was verified by comparison to productivity levels determined using traditional oxygen $\left(\mathrm{O}_{2}\right)$ evolution. Linear regression analyses of the primary productivities obtained using the $\mathrm{CF}\left(P_{\mathrm{CF}}\right)$ and $\mathrm{O}_{2}\left(P_{\mathrm{O} 2}\right)$ techniques showed good fits to the equation $P_{\mathrm{O} 2}=0.91 P_{\mathrm{CF}}\left(n=7, r^{2}=0.876, p<0.01\right)$, and the slope was not significantly different from $1 . P_{\mathrm{CF}}$ continuously estimated during the study period varied from 0.28 $-6.59 \mathrm{~g} \mathrm{O}_{2} \mathrm{~m}^{-2} \mathrm{~d}^{-1}\left(0.09-2.01 \mathrm{~g} \mathrm{C} \mathrm{m}^{-2} \mathrm{~d}^{-1}\right)$, within the range of previously published values. The high resolution of primary productivity at a daily scale obtained with this method will allow precise estimates of the annual production in lakes.
\end{abstract}

Key words : Phytoplankton, Primary production, Pulse amplitude modulated (PAM) fluorescence, Oxygen evolution, Electron transport rate (ETR)

\section{摘 要}

クロロフィル励起蛍光に基づいた方法 (CF 法) により, 琵琶湖における植物プランクトン一次生産力 $(\mathrm{g}$ $\mathrm{O}_{2} \mathrm{~m}^{-2} \mathrm{~d}^{-1}$ ) を測定し, その有効性を確かめるために酸素法 (ボトル培養法) で求めた一次生産力と比較した。 その結果, $\mathrm{CF}$ 法と酸素法で測定した日間一次生産力（それぞれ， $P_{\mathrm{CF}}$ と $P_{\mathrm{O} 2}$ ）の間には $P_{\mathrm{O} 2}=0.91 P_{\mathrm{CF}}$ の直 線関係が認められ $\left(n=7, r^{2}=0.876, p<0.01\right)$ ， その傾きと 1 との間に有意差はなかった。また，2012 年 4 月 17 日〜 12 月 17 日の期間, $P_{\mathrm{CF}}$ は $0.28 \sim 6.59 \mathrm{~g} \mathrm{O}_{2} \mathrm{~m}^{-2} \mathrm{~d}^{-1}\left(0.09 \sim 2.01 \mathrm{~g} \mathrm{C} \mathrm{m}^{-2} \mathrm{~d}^{-1}\right)$ の範囲で大きく変 動した。これらの值は，これまでに求められた日間一次生産力の範囲内に収まったが，観測された日変 動は月間あるいは年間の一次生産力を求める際により正確な值を与えられることを示唆した。 


\section{キーワード 植物プランクトン, 一次生産力, パルス変調（PAM）式クロロフィル励起蛍光光度計, 酸 素発生量, 電子伝達速度（ETR）}

(2013 年 3 月 22 日受付；2013 年 5 月 21 日受理)

\section{はじめに}

植物プランクトンは水圈生態系における主要な一次 生産者であり，水圈生態系の根幹を支える極めて重要な 役割を担っている。そのため, 植物プランクトンの一次 生産力を正確に把握することは水圈における生物生産過 程の解明や水産資源の維持・管理において重要な意味を 有する。これまで植物プランクトン一次生産力の測定に は, 光合成に伴う酸素発生量を測定する方法 (酸素法) と，炭素同位体をトレーサーに用いてその取り込み量を

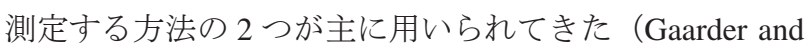
Gran, 1927; Steemann-Nielsen, 1952)。これらの手法はい ずれも測定に多くの時間を必要とし, また実験操作も 煩雑であるため, 現場における連続的な測定は不可能で あった。通常, これらの手法を用いた植物プランクトン の一次生産に関する研究では, 月に数回あるいは年に数 回程度の測定結果に基づいて, 年間の一次生産力を推定 している。しかし, 現場植物プランクトンの一次生産力 は環境因子 (水温, 栄養塩, 日射量など) と植物プラン クトンの生理状態や種組成に応じて常に変動するため, 従来行われてきた断続的なデータに基づく評価では大き な誤りを含む可能性があった。

一方, 近年では, クロロフィル励起蛍光を用いて植 物プランクトンの光合成に関する情報を短時間に, か つ簡易に測定できる技術が発達してきた。例えば, Fast Repetition Rate (FRR) 法 (Kolber et al., 1998; Smyth et al., 2004), Pump and Probe (P and P) 法 (Mauzerall, 1972; Falkowski et al., 1986), Pulse Amplitude Modulation (PAM) 法（Schreiber et al., 1986, 1995b) などが挙げられる。このうち, PAM 法は世界的に最も広く使われている方法の一つで (Schreiber et al., 1986, 1995b), 光合成に有効なパルス変 調された励起光を植物プランクトン細胞に照射すること によって, 電子伝達系における光化学系 II（PSII）の電 子受容体を還元した状態へと変化させ，その時発生する 生体内クロロフィル蛍光の強度変化から, PSII に抢け る最大量子収率 $(\mathrm{Fv} / \mathrm{Fm})$ や, 光照射下の電子伝達速度 (ETR) などを短時間に, かつ容易に測定することができ る。PSII に抢ける電子伝達は光合成に伴う酸素発生と
連結した反応であるため, ETR から総酸素発生量を推 定する研究が数多く行われた (Beer et al., 1998; Carr and Björk, 2003; Figueroa et al., 2003; Beer and Axelsson, 2004; Silva and Santos, 2004)。Goto et al. (2008) は, PAM 法と 酸素法からそれぞれ得られた光合成一光 (PI) 曲線が 強光部分を除いて良く一致することを見出している。

本研究では, このPAM 法を用いて得られた PI 曲線と 現場で測定された光量子量から, 連続的に一次生産力を 測定する方法を提案し, 酸素法と比較する事によって, その有効性について検討した。以後, これをChlorophyll fluorescence (CF) 法と呼び酸素法と区別する。加えて, $\mathrm{CF}$ 法によって 2012 年 4 月から 12 月の琵琶湖北湖にお ける植物プランクトンの日間一次生産力を求め, これま での知見と比較した。

\section{方 法}

試料採取と係留システム

現場における植物プランクトン一次生産力を CF 法と 酸素法にて同時に測定するため, 2012 年 5 月 8 日, 6 月 14 日, 7 月 18 日, 8 月 16 日, 10 月 30 日, 11 月 5 日, 12 月 12 日のそれぞれの日に琵琶湖北湖の定点 K4 $\left(35^{\circ}\right.$ $18.94^{\prime} \mathrm{N}, 136^{\circ} 11.45^{\prime} \mathrm{E}$ ，水深約 $48 \mathrm{~m}$ ） でバンドーン採 水器を用いて 3 媣度 $(5 \mathrm{~m}, 10 \mathrm{~m}, 15 \mathrm{~m})$ から試水を採 取し, 実験室まで持ち帰った (Fig. 1)。持ち帰った試水は, 植物プランクトンの光吸収係数およびクロロフィル $a$ 濃 度測定用に，それぞれガラス繊維濾紙（GF/F, Whatman） に濾過し, 測定までの間, $-80^{\circ} \mathrm{C}$ で保存した。採水と同 時に, 多項目水質計 (ACL220-DK, ALEC) により, 水 温と水中光量子量を湖底直上まで鉛直的に測定した。

湖水中のクロロフィル $a$ 濃度と水中光量子量を連続的 に測定するため, 2012 年 4 月 17 日から 8 月 26 日まで と, 10 月 10 日から 12 月 17 日までの期間, 琵琶湖北湖 の定点 K4 にクロロフィル蛍光光度計 (ACLW-USB およ び ACLW-CMP, JFE ALEC）と水中光量子計（ALW-CMP, JFE ALEC）を係留した（Fig. 1)。クロロフィル蛍光光 度計は 3 深度 $(5 \mathrm{~m}, 10 \mathrm{~m}, 15 \mathrm{~m})$ に, 水中光量子計は 2 深度 $(5 \mathrm{~m}, 10 \mathrm{~m})$ にそれぞれ設置し, いずれも 20 分 


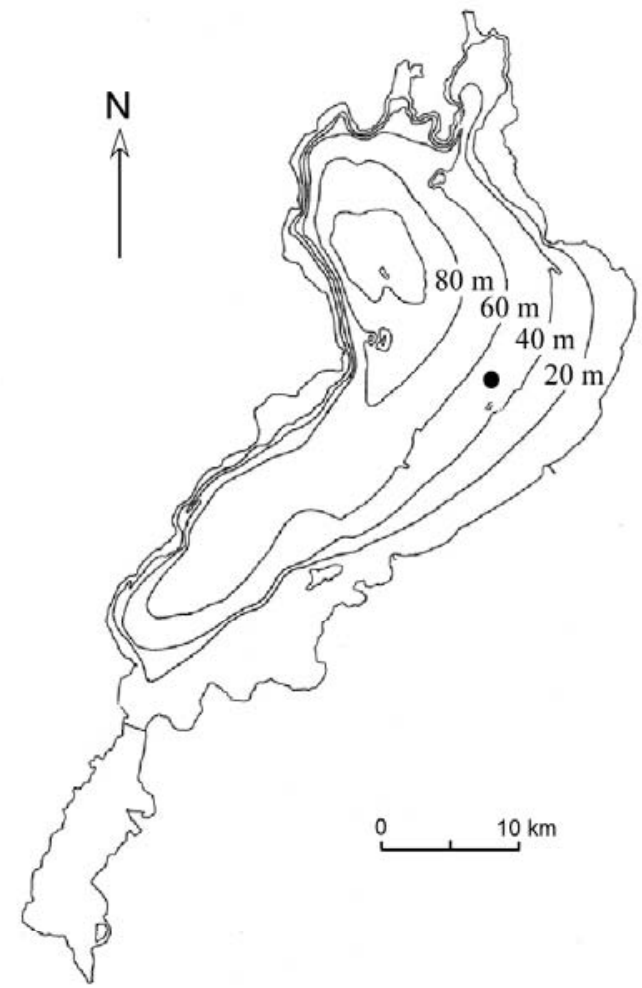

Fig. 1. Map of Lake Biwa, Shiga Prefecture, Japan, showing the sampling location and the mooring site of Station K4 (solid circle).

図 1. 琵琶湖北湖における調査・係留定点 $\mathrm{K} 4$
間隔でデータを記録した（Fig. 2)。クロロフィル蛍光光 度計のクロロフィル $a$ 濃度は, 毎月アセトン抽出して測 定したクロロフィル $a$ 濃度で校正した。校正には, 採水 時の前後 1 時間の蛍光光度計の蛍光強度を平均して用い た。なお, 水深 $15 \mathrm{~m}$ の水中光量子量 $\left(I_{15}\right)$ は, 水深 5 $\mathrm{m}$ と $10 \mathrm{~m}$ の水中光量子量から鉛直光消散係数 $(k)$ を算 出し, 以下の式（1）を用いて推定した。

$$
I_{15}=I_{0} \exp (-15 k)
$$

ここで， $I_{0}$ は水深 $0 \mathrm{~m}$ における光量子量を示す。一方, 補償深度 $\left(Z_{\mathrm{e}}\right)$ は, 相対水中光量子量が $1 \%$ に相当する 水深として式（2）加算出した。

$$
Z_{\mathrm{e}}=-1 / k \cdot \ln 0.01
$$

本研究に使用した水中光量子計は下向光量子量 $\left(I_{\mathrm{d}}\right)$ の夕を測定するため, 適宜, スカラー光量子計（LI-193, LI-COR）を用いて, スカラー光量子量 $(I)$ の測定も行い, これらの比 $\left(I / I_{\mathrm{d}}\right)$ を求めることで， $I_{\mathrm{d}}$ を $I$ に変換した。

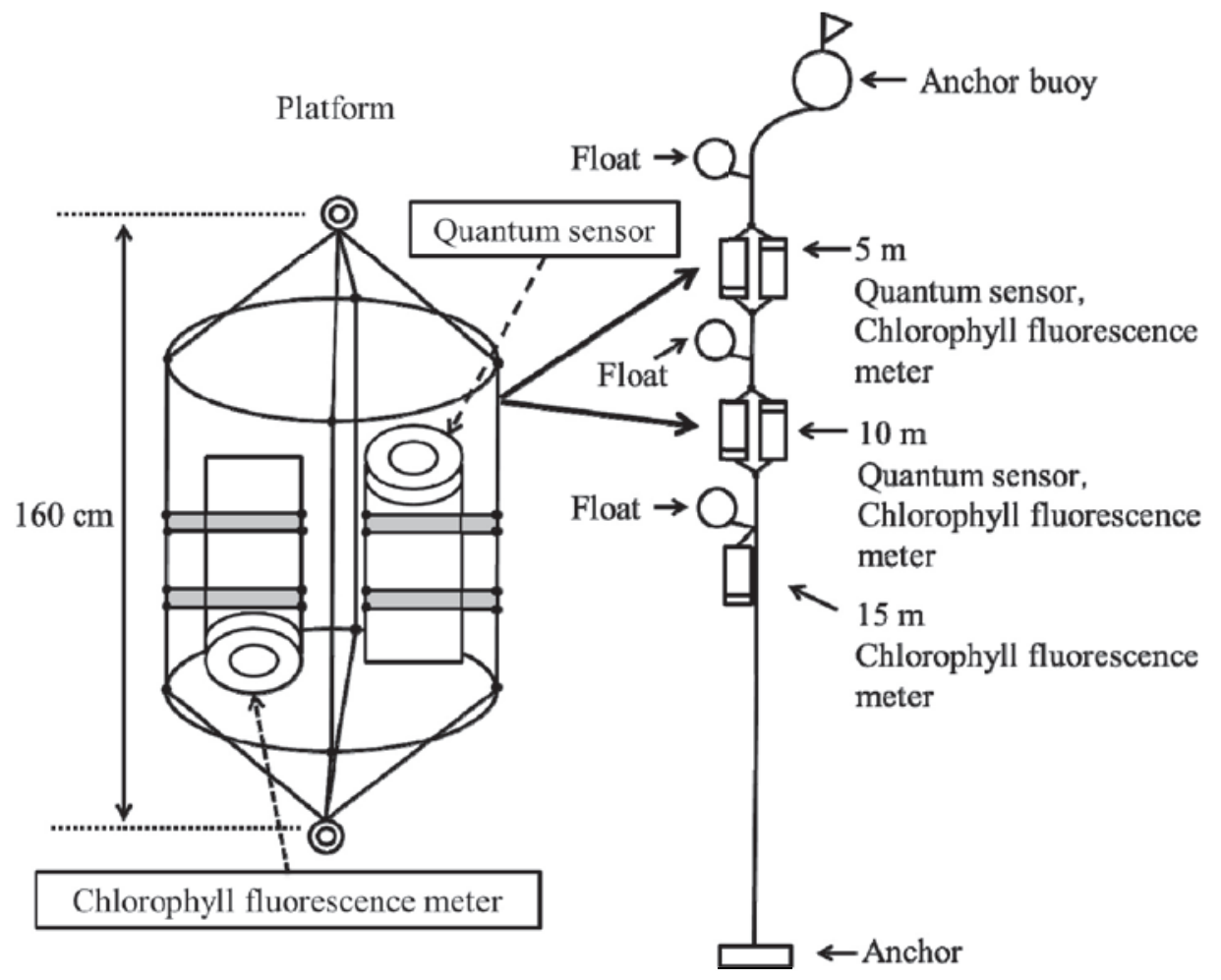

Fig. 2. Schematic diagram of the mooring system.

図 2. 定点 $\mathrm{K} 4$ に設置した係留系の概略図. 


\section{CF 法に基づく一次生産力の測定}

7 回の各実験日および 4 月 17 日の係留系設置時に採 取した試水中の植物プランクトン群集に対して PI 曲 線を求めるため, PAM 式クロロフィル励起蛍光光度計 （Water-PAM, Walz）を用いて採水時の現場水温下，0～ $2000 \mu \mathrm{mol}$ quanta $\mathrm{m}^{-2} \mathrm{~s}^{-1}$ の 8 段階の光量子量で PSII にお ける量子収率（Yield）を測定し（Genty et al., 1989），以 下の式（3）により電子伝達速度（ETR, $\mu \mathrm{mol}$ electron $\mathrm{mg}$ chl. $\left.a^{-1} \mathrm{~s}^{-1}\right)$ を算出した（Schreiber et al. 1995a）。

$$
\text { ETR }=\text { Yield } \cdot \text { PAR } \cdot a^{*} \cdot 0.5
$$

ここで, $P A R$ は光合成有効放射（可視光域 $400 \sim 750$ $\mathrm{nm}$ における光量子量), $a^{*}$ はPARにおける単位ク口ロ フィル $a$ 濃度当たりの平均光吸収係数を示す。なお PSI

と PSII の光エネルギー配分率は 1:1 と仮定した。

$a^{*}$ は Quantitative Filter Technique (QFT) 法で求め た（Kishino et al., 1985）。濾紙上に捕集された可視光域 の全粒子状物質の吸光度 $\left(O D_{\mathrm{f}}\right)$ を分光光度計（V-560, Jasco）にて測定し, 式（4）により試水中の懸濁物質の 吸光度 $\left(O D_{\mathrm{s}}\right)$ を算出した（Mitchell, 1990）。

$$
O D_{\mathrm{s}}=0.392 O D_{\mathrm{f}}+0.655\left(O D_{\mathrm{f}}\right)^{2}
$$

さらに, 式（5）により吸収波長（入）における懸濁物 質の光吸収係数 $\left(a_{\mathrm{p}}(\lambda)\right)$ を求めた。

$$
a_{\mathrm{p}}(\lambda)=2.3 O D_{\mathrm{s}} \cdot S / V
$$

ここで, $S$ は濾紙の濾過面積 $\left(\mathrm{m}^{2}\right), V$ は試水の濾過容 量 $\left(\mathrm{m}^{3}\right)$ を示す。続いて, 滤紙上の植物色素をメタノー ルで 1 時間以上抽出した後に再び吸光度を測定すること によって植物プランクトン以外の懸濁物質の光吸収係数 $\left(a_{\mathrm{d}}(\lambda)\right)$ を求めた。植物プランクトンの光吸収係数 $\left(a_{\mathrm{ph}}\right.$ $(\lambda))$ は， $a_{\mathrm{p}}(\lambda)$ から $a_{\mathrm{d}}(\lambda)$ を差し引くことで求め ることができる。結局， $a^{*}$ は吸収波長 $400 \sim 750 \mathrm{~nm}$ に おける $a_{\mathrm{ph}}(\lambda)$ の平均值を別途求めたクロロフィル $a$ 濃度で除することで得た。試水中のクロロフィル $a$ 濃度 は，測定用に保存した濾紙を $90 \%$ アセトン溶液に 24 時 間浸漬し，濾紙上に捕集された植物プランクトンから 色素を抽出した後, 抽出液の蛍光強度を分光蛍光光度計 (RF-1500, Shimadzu) にて測定することで求めた（Parsons et al., 1984)。

各水中光量子量 $(I)$ における一次生産力 $\left(P: \mu \mathrm{g} \mathrm{O}_{2}\right.$ mg chl. $\left.a^{-1} \mathrm{~s}^{-1}\right)$ は, ETR に対する酸素量のモル比 $\left(\mathrm{O}_{2} /\right.$ $E T R$ )を 0.117 (年間平均值）として算出し（Goto et al., 2008), 式（6）を用いて非線形回帰にて求めた（Platt et al., 1980)。

$$
P=P_{\mathrm{s}}\left[1-\exp \left(-\alpha I / P_{\mathrm{s}}\right)\right]\left[\exp \left(-\beta I / P_{\mathrm{s}}\right)\right]
$$

ここで, $P_{\mathrm{s}}$ は強光阻害がない時の最大光合成速度（最 大一次生産力), $\alpha$ は初期傾斜, $\beta$ は強光阻害係数を示寸。

最終的に, 各実験日における 3 深度の $P$ は 20 分毎に 得られた水中光量子量とそれぞれの月に得られた PI 曲 線から求めた。ただし，それぞれ一ヶ月間は同じPI 曲 線を用いた。求めた $P$ に係留したクロロフィル蛍光光 度計より求めたクロロフィル $a$ 濃度を乗じることで単位 体積当たりの一次生産力を算出した。これを補償深度ま で台形積分することで水柱当たりの一次生産力を求め, さらにこれを時間積分することで日間一次生産力 $\left(P_{\mathrm{CF}}: \mathrm{g}\right.$ $\left.\mathrm{O}_{2} \mathrm{~m}^{-2} \mathrm{~d}^{-1}\right)$ とした。

\section{酸素法による植物プランクトン一次生産力の測定}

7 回の各実験日において 3 深度から採取した試水は, 船上にてそれぞれ 4 本のフラン瓶（容量 $300 \mathrm{ml}$ ）に静 かに分注した。これらのらち2本は明瓶としてそのま ま, 残り 2 本は暗瓶としてアルミホイルで包み完全に遮 光し, 再び採水深度に垂下し, 24 時間培養した。培養後, 船上にてすべての瓶に直ちに 2 種の試薬（塩化マンガン 溶液, ヨウ化ナトリウムー水酸化ナトリウム溶液）を添 加し, 溶存酸素を固定して実験室に持ち帰った。持ち帰っ た試料の溶存酸素量は, 24 時間以内に電位差自動滴定 器 (716 DMS, Metrohm) を用いてウインクラー法 (精度 : $\pm 0.2 \mu \mathrm{mol} \mathrm{L}^{-1}$ ) にて測定した（Carignan et al., 1998）。 各水深の単位体積当たりの日間一次生産力は, 明瓶の溶 存酸素量から暗瓶の溶存酸素量を差し引き, 培養時間で 除すことで算出した。水柱当たりの日間一次生産力 $\left(P_{\mathrm{O} 2}\right.$ : $\left.\mathrm{g} \mathrm{O}_{2} \mathrm{~m}^{-2} \mathrm{~d}^{-1}\right)$ は, 上記で求めた各水深の一次生産力を水 面から補償深度まで積算して求めた。

\section{統計検定}

$P_{\mathrm{CF}}$ と $P_{\mathrm{O} 2}$ を比較するため, 回帰分析を行った。また, 得られた回帰式の傾きが 1 と有意に異なるか確かめるた めに両側 $t$ 検定を行った。 


\section{結 果}

本研究において, 7 回の調査時に湖水表面直下の日積 算光量子量は $5.7 \sim 35.0 \mathrm{~mol}$ quanta $\mathrm{m}^{-2} \mathrm{~d}^{-1}$ の範囲で変動 し，5月から 8 月にかけて高くなり 10 月から 12 月にか けて大きく減少した（Table 1)。補償深度は 15.4〜 23.6 $\mathrm{m}$ の範囲で変動し，8月に最大であった（Table 1)。

本研究期間を通して, $P_{\mathrm{CF}}$ は $0.28 \sim 6.59 \mathrm{~g} \mathrm{O}_{2} \mathrm{~m}^{-2} \mathrm{~d}^{-1}$ の 範囲で日々大きく変動し, 春期と夏期に高く, 梅雨期と 冬期に低くなる傾向を示した（Fig. 3)。この期間，ク口
ロフィル $a$ 濃度は $P_{\mathrm{CF}}$ の変動とは必ずしも一致せず, 水 深 $5 \mathrm{~m}$ と $10 \mathrm{~m}$ では $1.65 \sim 18.3 \mathrm{mg} \mathrm{m}^{-3}$ の範囲で変動し 6 月から 7 月にかけて最大值を示したのに対して, 水深 $15 \mathrm{~m}$ では 3.21 〜 $10.3 \mathrm{mg} \mathrm{m}^{-3}$ で顕著な季節変動を示さな かった（Fig. 3)。 $P_{\mathrm{O} 2}$ は 7 回に渡って測定したが，1.27 〜 $4.45 \mathrm{~g} \mathrm{O}_{2} \mathrm{~m}^{-2} \mathrm{~d}^{-1}$ の範囲で変動し, このとき $P_{\mathrm{CF}}$ はほぼ 同様の值を示した（Table 1, Fig. 4）。回帰分析の結果は, $P_{\mathrm{O} 2}$ と $P_{\mathrm{CF}}$ との間に以下の直線関係が認められることを 示し (Fig. 5a),

Table 1. Daily photon flux density at the lake surface, compensation depth, and primary productivity measured by chlorophyll fluorescence $\left(P_{\mathrm{CF}}\right)$ and oxygen evolution $\left(P_{\mathrm{O} 2}\right)$ at Station $\mathrm{K} 4$ in the north basin of Lake Biwa, Japan, from May to December, 2012.

表 1. 2012 年 5 月から 12 月の琵琶湖北湖定点 K4 における、湖表面の日積算光量子量, 補償深度, および $\mathrm{CF}$ 法 $\left(P_{\mathrm{CF}}\right)$ と酸素法 $\left(P_{\mathrm{O} 2}\right)$ で測定した日間一次生産力.

\begin{tabular}{|c|c|c|c|c|}
\hline \multirow{2}{*}{ Date } & \multirow{2}{*}{$\begin{array}{l}\text { Daily photon flux density } \\
\left(\text { mol quanta } \mathrm{m}^{-2} \mathrm{~d}^{-1}\right)\end{array}$} & \multirow{2}{*}{$\begin{array}{l}\text { Compensation depth } \\
(\mathrm{m})\end{array}$} & \multicolumn{2}{|c|}{ Primary productivity $\left(\mathrm{g} \mathrm{O}_{2} \mathrm{~m}^{-2} \mathrm{~d}^{-1}\right)$} \\
\hline & & & $P_{\mathrm{CF}}$ & $P_{\mathrm{O} 2}$ \\
\hline 8 May 2012 & 22.2 & 16.0 & 3.15 & 2.74 \\
\hline 14 Jun 2012 & 35.0 & 16.6 & 3.29 & 3.63 \\
\hline 18 Jul 2012 & 27.4 & 15.4 & 4.66 & 4.45 \\
\hline 16 Aug 2012 & 34.3 & 23.6 & 3.83 & 2.92 \\
\hline 30 Oct 2012 & 9.4 & 18.6 & 3.32 & 3.00 \\
\hline 5 Nov 2012 & 6.3 & 18.0 & 2.21 & 1.85 \\
\hline 12 Dec 2012 & 5.7 & 15.8 & 1.28 & 1.27 \\
\hline
\end{tabular}

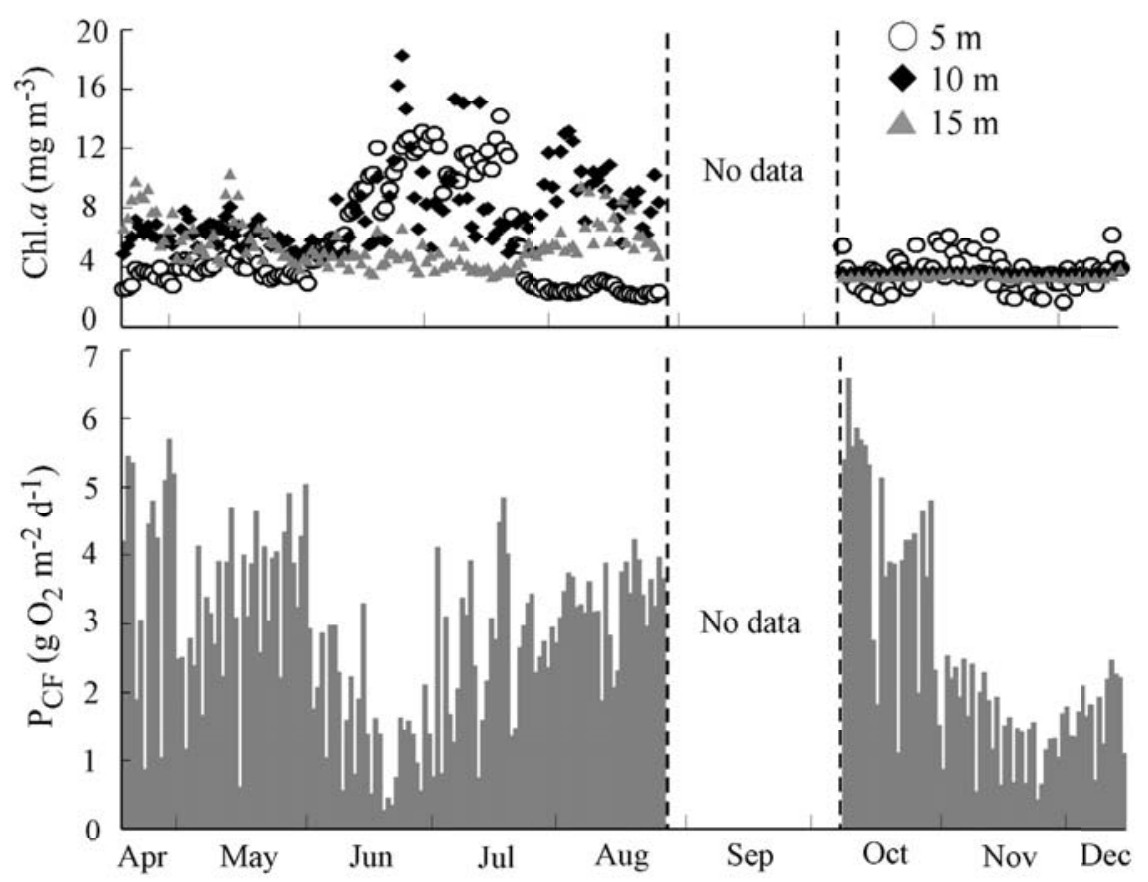

Fig. 3. Seasonal variation in chlorophyll $a(\mathrm{Chl} . a)$ concentration and daily primary productivity estimated by chlorophyll fluorescence $\left(P_{\mathrm{CF}}\right)$ at Station K4 in the north basin of Lake Biwa, Japan, from April to December, 2012. Indicated Chl.a concentrations are mean daytime (9:00 - 15:00) values measured at $20 \mathrm{~min}$. intervals.

図 3. 2012 年 4 月から 12 月の琵琶湖北湖定点 $\mathrm{K} 4$ におけるクロロフィル $a$ 濃度 $(\mathrm{Chl} . a)$ と CF 法 $\left(P_{\mathrm{CF}}\right)$ で測定した日間一次生 産力の季節変動。Chl. $a$ は日中（9 時〜 15 時: クロロフィル蛍光計により 20 分間隔で測定）の平均值を一日毎に図示した。 


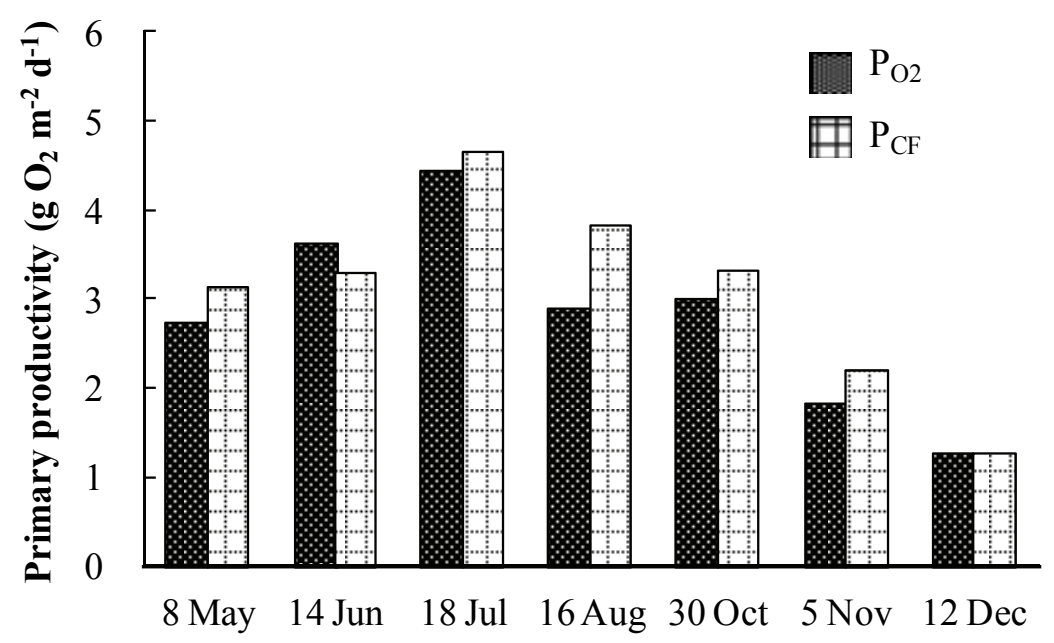

Fig. 4. Daily primary productivity estimated by chlorophyll fluorescence $\left(P_{\mathrm{CF}}\right)$ and oxygen evolution $\left(P_{\mathrm{O} 2}\right)$ at Station $\mathrm{K} 4$ in the north basin of Lake Biwa, Japan, from May to December, 2012.

図 4. 2012 年 5 月から 12 月の琵琶湖北湖定点 $\mathrm{K} 4$ における $\mathrm{CF}$ 法 $\left(P_{\mathrm{CF}}\right)$ と酸素 法 $\left(P_{\mathrm{O} 2}\right)$ で測定した日間一次生産力.
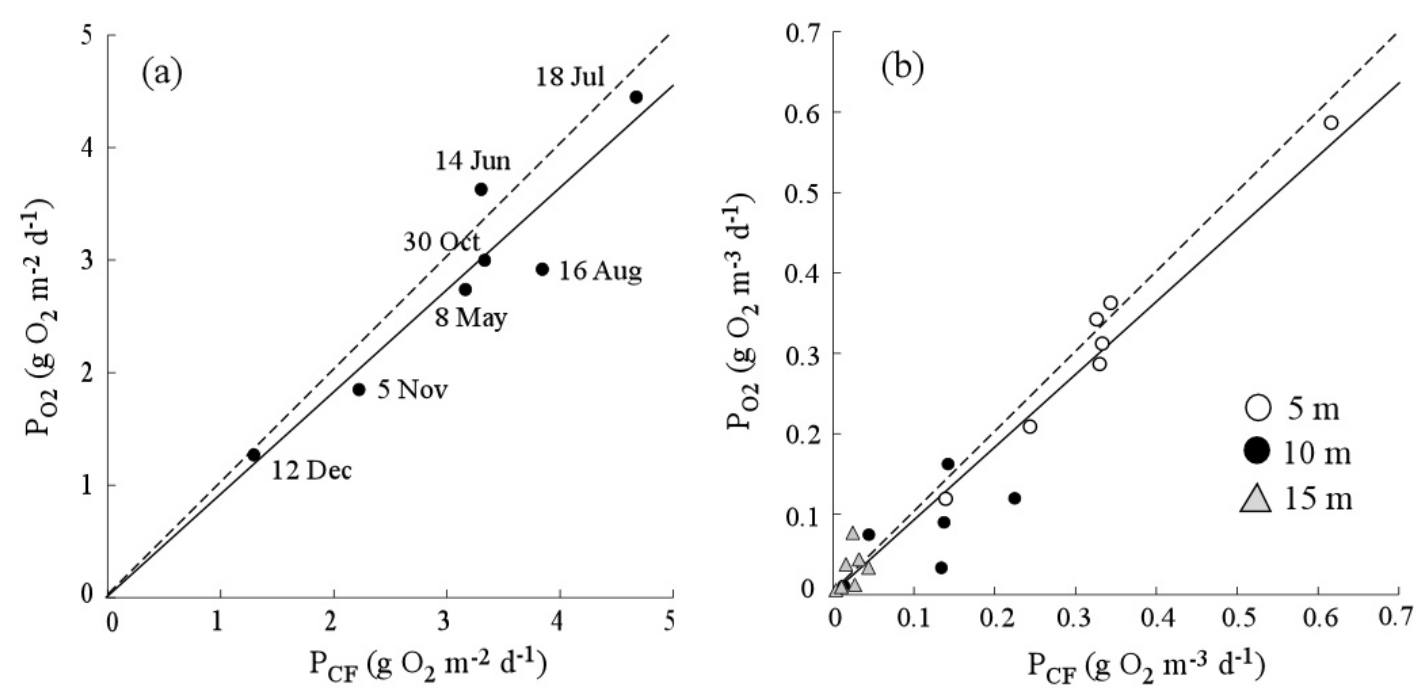

Fig. 5. Comparison between the daily primary productivity in the water column (a) and per unit volume at each depth (b) measured by chlorophyll fluorescence $\left(P_{\mathrm{CF}}\right)$ and oxygen evolution $\left(P_{\mathrm{O} 2}\right)$. The solid line represents the linear regression equation fitted with $P_{\mathrm{O} 2}$ against $P_{\mathrm{CF}}$. The dashed line indicates the $P_{\mathrm{CF}}=P_{\mathrm{O} 2}$ line.

図 5. $\mathrm{CF}$ 法 $\left(P_{\mathrm{CF}}\right)$ と酸素法 $\left(P_{\mathrm{O} 2}\right)$ で測定した水柱当たり（a）と各深度における単位体積当たり（b）の日間 一次生産力の比較。実線は $P_{\mathrm{O} 2}$ と $P_{\mathrm{CF}}$ の回帰直線を, 点線は $P_{\mathrm{CF}}=P_{\mathrm{O} 2}$ ラインを示す.

$$
P_{\mathrm{O} 2}=0.91 P_{\mathrm{CF}}\left(n=7, r^{2}=0.876, p<0.01\right)
$$

この直線の傾きは 1 と有為に異なることはなかった (Two-tailed $t$-test, $n=7, t=-0.575, p>0.05$ )。また，単位 体積あたりの一次生産力として深度毎の $P_{\mathrm{O} 2}$ と $P_{\mathrm{CF}}$ を比
較すると, 水深 $5 \mathrm{~m}$ では両者間に有意な直線関係 $(n=7$, $r^{2}=0.971, p<0.01 ）$ が認められたが, 水深 $10 \mathrm{~m}$ と $15 \mathrm{~m}$ では両者間に有意な直線関係は認められなかった $(10 \mathrm{~m}$, $n=7, r^{2}=0.40, p>0.05 ; 15 \mathrm{~m}, n=7, r^{2}=0.18, p>0.05$ ) (Fig. $5 b)$ 。 


\section{考 察}

本研究期間において, $P_{\mathrm{O} 2}$ と $P_{\mathrm{CF}}$ の間には直線関係が 認められ, その直線の傾きは 1 との間に有意差なく, $P_{\mathrm{O} 2}: P_{\mathrm{CF}}$ はほぼ $1: 1$ で対応した（Fig. 5a)。このことは, $\mathrm{CF}$ 法を用いることで, 水柱当たりの日間一次生産力 $(\mathrm{g}$ $\left.\mathrm{O}_{2} \mathrm{~m}^{-2} \mathrm{~d}^{-1}\right)$ が従来の酸素法と比較可能な状態で, 連続的 に測定できることを示す。深度毎に $P_{\mathrm{O} 2}$ と $P_{\mathrm{CF}}$ を比較す ると, 水深 $5 \mathrm{~m}$ に扔ける両者間には有意な直線関係が認 められたのに対して, 水深 $10 \mathrm{~m}$ と $15 \mathrm{~m}$ ではこのよう な関係は認められなかった。これは, 水深 $10 \mathrm{~m}$ と $15 \mathrm{~m}$ における一次生産力が低かったため, 精度良く測定でき なかったことが原因かもしれない。

本研究結果から, 植物プランクトンの一次生産力を 従来の酸素法とほぼ同じ精度で $\mathrm{CF}$ 法により測定でき ることが明らかとなった。しかし，8月16日のように $P_{\mathrm{O} 2} / P_{\mathrm{CF}}$ 比が 1 から大きく外れる場合があった（Fig. 5a)。 この主な原因の一つは, CF 法において測定した ETRを 酸素発生速度に変換するための係数と考えられる。琵 琶湖北湖における $\left(\mathrm{O}_{2} /\right.$ ETR $)$ は, 年間を通して $0.08 \sim 1.81$ (平均 0.117 ) の 範囲で変動するが, その明確な季節的変動傾向は認めら れていない (Goto et al., 2008)。このため, 本研究では その年平均値 $(0.117)$ を変換係数として用いた。この ことが $P_{\mathrm{O} 2}$ と $P_{\mathrm{CF}}$ の乘離につながった可能性がある。

この他にも, ETR を求める際に用いる植物プランクト ンの平均光吸収係数 $a^{*}$, あるいはPSI と PSII の間の工 ネルギー配分率の設定が $P_{\mathrm{O} 2}$ と $P_{\mathrm{CF}}$ の乘離に影響を与え る可能性がある。本研究では QFT 法を用いて $a^{*}$ を測定 したが (Kishino et al., 1985; Mitchell, 1990), 試料中にフィ コビリンタンパク質を含む藍藻やクリプト藻類が含まれ ていると, メタノールで植物色素が充分抽出されない場 合のあることが知られている (Ferrari and Tassan, 1999)。 即ち, 試料中にこれら藻類が多く含まれていた場合には, 植物色素の抽出が不十分となり, $a^{*}$ が過小評価される 可能性がある。また, 本研究では PSI と PSII 間の光エ ネルギー配分率を 0.5 と設定したが, 琵琶湖北湖におけ る植物プランクトン群集に対する光エネルギー配分率の 季節変動を調べた研究例はまだないのが現状である。

本研究では CF 法と酸素法によって求妨机る一次生 産力を比較したが, 酸素法が必ずしも真の值であると は限らない。例えば, 酸素法は明所と暗所における植 物プランクトンの暗呼吸が同じと仮定して一次生産量 を算出しているが，植物プランクトンの暗呼吸は明所と
暗所では異なる場合が知られている (Geider and Osborn, 1989; Villar et al. 1995)。また, 植物プランクトンによる 二次的な酸素消費（光呼吸やメーラー反応）が生じた 場合, 酸素法では総酸素発生量を過小評価することにな る (Falkowski et al., 1985; Grande et al., 1989, 1991; Kana, 1992, 1993; Beardall et al., 2003; D’Ambrosio et al., 2006)。 このとき, $P_{\mathrm{CF}}$ は $P_{\mathrm{O} 2}$ に対して相対的に高く計算される。 これら CF 法と酸素法の問題点についてより詳しく検討 することによって, CF 法による一次生産力の測定精度 を向上させることができるだろう。

本研究において $P_{\mathrm{CF}}$ は日々大きく変動したが，季節的 には日射量が増加する春期から夏期にかけて（6月の梅 雨期を除く）高くなる傾向を示した（Fig. 3)。一方，こ の一次生産力にみられた変動は必ずしもクロロフィル $a$ 濃度の変動とは一致しなかった。このような一次生産 力とクロロフィル現存量の不一致壮高解像度で観測する ことによって初めて明らかにすることができるものであ り, 新たな研究の展開が期待される。

本研究期間に得られた $P_{\mathrm{CF}}$ は, これまでに琵琶湖で得 られた光合成商（1.23）（Goto et al., 2008）で炭素量に換 算すると $0.09 \sim 2.01 \mathrm{~g} \mathrm{C} \mathrm{m}^{-2} \mathrm{~d}^{-1}$ と計算できる。これらの 值はこれまでに琵琶湖北湖で測定された日間一次生産量 の範囲内に充分収まった $\left(0.28 \sim 1.29 \mathrm{~g} \mathrm{C} \mathrm{m}^{-2} \mathrm{~d}^{-1}\right.$, Urabe et al., 1995; $0.1 \sim 2.7 \mathrm{~g} \mathrm{C} \mathrm{m}^{-2} \mathrm{~d}^{-1}$, 中西ら, 2001; $0.25 \sim 2.20$ $\mathrm{g} \mathrm{C} \mathrm{m}^{-2} \mathrm{~d}^{-1}$, Yoshimizu et al., 2002)。

本研究では, PI 曲線が一ヶ月間一定であると仮定し て $P_{\mathrm{CF}}$ を見積もった。しかし実際には, PI 曲線は常に変 動すると考えられるため, 日間一次生産力をより精度良 く測定するためには, より高頻度で PI 曲線を測定する 必要がある。琵琶湖の場合, 栄養盐濃度や植物プランク トン種組成の時間変動を考慮すれば， $1 \sim 2$ 週間間隔で PI 曲線を測定することが望ましい。本研究では月一回 の頻度で測定したが, CF 法では PAM 式クロロフィル励 起蛍光光度計を用いることによって極めて簡便に PI 曲 線を得ることができるため, 実際には一ヶ月に数回の頻 度での測定も可能である。また現在では, 水中係留型の クロロフィル励起蛍光計も市販されており, このような 測器を利用すれば, より高頻度で現場における PI 曲線 を測定することができる。ただし，これらの測器は極め て高価である。これに対して CF 法は比較的安価に実施 することができる利点を有する。

これまで報告されてきた月間または年間一次生産力 は, 短期間の変動を考慮せず, せいぜい 1 ケ月毎に低頻 度で得た代表値から推定されるに過ぎなかった。本研究 
で提案する CF 法では植物プランクトンの日間一次生産 力を連続的に測定することが可能であり，これらは大き な日変動を示すことが明らかとなった。従来法では得ら れなかったこのような高解像度のデータセットは湖の一 次生産力を正しく定量するために極めて重要な意味を持 つが，それだけに留まらず，極短期間の変動を捉えるこ とが可能となり，これまでは明らかにできなかった湖内 部で生じる日単位の変動に対する植物プランクトン生産 の応答を解析することが可能になると期待できる。

\section{謝 辞}

本研究を行うに当たり, 琵琶湖環境科学研究センター の熊谷道夫博士（現立命館大学教授）には調查船「はっ けん」による観測および係留システムの設置および回収 に, そして滋賀県立大学の海外文一郎氏には実習調査船 「はっさか」による観測にご協力いただいた。また，滋 賀県立大学環境生態学科の学生諸氏には, 船舶による調 查の際にご協力いただいた。ここに記して感謝の意を表 す。なお，本研究滋賀県立大学重点領域研究として行 われ，一部は JSPS 科研費 24510015 ならびに（財）河川 環境管理財団河川整備基金助成事業から助成を受けた。

\section{文 献}

Beardall, J., J. Quigg and J. A. Raven (2003): Oxygen consumption: Photorespiration and Chlororespiration. In Photosynthesis in Algae (Advances in Photosynthesis and Respiration vol. 14), Larkum, A. W. D., S. E. Douglas and J. A. Raven (eds.): 157-181. Kluwer Academic Publishers, Dordrecht.

Beer, S. and L. Axelsson (2004): Limitations in the use of PAM fluorometry for measuring photosynthetic rates of macroalgae at high irradiances. European Journal of Phycology, 39: 1-7.

Beer, S., B. Vilenkin, A. Weil, M. Veste, L. Susel and A. Eshel (1998): Measuring photosynthetic rates in seagrasses by pulse amplitude modulated (PAM) fluorometry. Marine Ecology progress Series, 174: 293-300.

Carignan, R., A. M. Blais and C. Vis (1998): Measurement of primary production and community respiration in oligotrophic lakes using the Winkler method. Canadian Journal of Fisheries and Aquatic Sciences, 55: 1078-1084.

Carr, H. and M. Björk (2003): A methodological comparison of photosynthetic oxygen evolution and estimated electron transport rate in tropical Ulva (Chlorophyceae) species under different light and inorganic carbon conditions. Journal of Phycology, 39: 1125-1131.

D’Ambrosio, N., C. Arena and A. V. de Santo (2006): Temperature response of photosynthesis, excitation energy dissipation and alternative electron sinks to carbon assimilation in Beta vulgaris L. Environmental and Experimental Botany, 55: 248-257.

Falkowski, P. G., Z. Dubinsky and K. Wyman (1985): Growth-irradiance relationships in phytoplankton. Limnology and Oceanography, 30: 311-321.

Falkowski, P. G., K. Wyman, A. C. Ley and D. C. Mauzerall (1986): Relationship of steady-state photosynthesis to fluorescence in eukaryotic algae. Biochimica et Biophysica Acta, 849: 183-192.

Ferrari, G. M and S. Tassan (1999): A method using chemical oxidation to remove light absorption by phytoplankton pigment. Journal of Phycology, 35: 1090-1098.

Figueroa, F. L., R. Conde-Álarez and L. Gómez (2003): Relationship between electron transport rates determined by pulse amplitude modulated chlorophyll fluorescence and oxygen evolution in macroalgae under different light conditions. Photosynthesis Research, 75: 259-275.

Gaarder, T and H. H. Gran (1927): Investigations of the production of plankton in the Oslo Fjord. Rapports et Proces-verbaux des Réunions. Conseil International pour l' Éxploration de la Mer, 42: 1-48.

Geider, R. J. and B. A. Osborn (1989): Respiration and microalgal growth: a review of the quantitative relationship between dark respiration and growth. New Phytologist, 112: 327-341.

Genty, B., J. M. Briantais and N. R. Baker (1989): The relationship between the quantum yield of photosynthetic electron transport and quenching of chlorophyll fluorescence. Biochemica et Biophysica Acta, 990: 87-92.

Goto, N., H. Miyazaki, N. Nakamura, H. Terai, N. Ishida and O. Mitamura (2008): Relationships between electron transport rates determined by pulse amplitude modulated (PAM) chlorophyll fluorescence and photosynthetic rates by traditional and common methods in natural freshwater phytoplankton. Fundamental and Applied Limnology / Archiv für Hydrobiologie, 172: 121-134.

Grande, K. D., M. L. Bender, B. Irwin and T. Platt (1991): 
A comparison of net and gross rates of oxygen production as a function of light intensity in some natural plankton populations in a Synechococcus culture. Journal of Plankton Research, 13: 1-16.

Grande, K. D., J. Marra, C. Langdon, K. Heinemann and M. L. Bender (1989): Rates of respiration in the light measured in marine phytoplankton using an ${ }^{18} \mathrm{O}$ isotope-labelling technique. Journal of Experimental Marine Biology and Ecology, 129: 95-120.

Kana,T. M. (1992): Relationship between photosynthetic oxygen cycling and carbon assimilation in Synechococcus WH7803 (Cyanophyta). Journal of Phycology, 28: 304-308.

Kana,T. M. (1993): Rapid oxygen cycling in Trichodesmium thiebautii. Limnology and Oceanography, 38: 18-24.

Kishino, M., M. Takahashi, N. Okami and S. Ichimura (1985): Estimation of the spectral absorption coefficients of phytoplankton in the sea. Bulletin of Marine Science, 37 : 634-642.

Kolber, Z. S., O. Prásil and P. G. Falkowski (1998): Measurements of variable chlorophyll fluorescence using fast repetition rate techniques: defining methodology and experimental protocols. Biochimica et Biophysica Acta, 1367: 88-106.

Mauzerall, D. (1972): Light-induced changes in Chiorella, and the primary photoreaction for the production of oxygen. Proceedings of the National Academy of Sciences of the United States of America, 69: 1358-1362.

Mitchell, B. G. (1990): Algorithms for determining the absorption coefficient of aquatic particulates using the quantitative filter technique (QFT). Ocean Optics X Proceedings of SPIE, 1302: 137-148.

中西正己・野崎健太郎・鏡味麻衣子 - 神松幸弘 (2001)： 琵琶湖の近況 植物プランクトン群集. 海洋化学研究, 14: 104-111.

Parsons T. R., Y. Maita and C. M. Lalli (1984): A manual of chemical and biological methods for seawater analysis. Pergamon Press, Oxford.

Platt, T., C. L. Gallegos and W. G. Harrison (1980): Photoinhibition of photosynthesis in natural assemblages of marine phytoplankton. Journal of Marine Research, 38: 687-701.

Schreiber, U., H. Hormann, C. Neubauer and C. Klughammer (1995a): Assessment of Photosystem II Photochemical
Quantum Yield by Chlorophyll Fluorescence Quenching Analysis. Australian Journal of Plant Physiology, 22: 209-220.

Schreiber, U., W. Bilger and C. Neubauer (1995b): Chlorophyll fluorescence as a nonintrusive indicator for rapid assessment of in vivo photosynthesis. In: Schulze, E. D. and Caldwell, M. M. (eds): 49-70. Ecophysiology of photosynthesis. Springer, Berlin.

Schreiber, U., U. Schliwa and W. Bilger (1986): Continuous recording of photochemical and non-photochemical chlorophyll fluorescence quenching with new type of modulation fluorometer. Photosynthesis Research, 10: 51-62.

Silva, J. and R. Santos (2004): Can chlorophyll fluorescence be used to estimate photosynthetic production in the seagrass Zostera noltii? Journal of Experimental Marine Biology and Ecology, 307: 207-216.

Smyth, T. J., K. L. Pemberton, J. Aiken and R. J. Geider (2004): A methodology to determine primary production and phytoplankton photosynthetic parameters from Fast Repetition Rate Fluorometry. Journal of Plankton Research, 26: $1337-1350$.

Steemann-Nielsen, E. (1952): The use of radioactive $\left({ }^{14} \mathrm{C}\right)$ for measuring organic production in the sea. Journal du Conseil / Conseil Permanent International pour l'Exploration de la Mer, 18: 117-140.

Urabe, J., M. Nakanishi and K. Kawabata (1995): Contribution of metazoan plankton to the cycling of nitrogen and phosphorus in Lake Biwa. Limnology and Oceanography, 40: 232-241.

Villar, R., A. A. Held and J. Merino (1995): Dark Leaf Respiration in Light and Darkness of an Evergreen and a Deciduous Plant Species. Plant Physiology, 107: 421-427.

Yoshimizu, C., J. Urabe, M. Sugiyama, M. Maruo, E. Nakayama and M. Nakanishi (2002): Carbon and phosphorus budgets in the pelagic area of Lake Biwa, the largest lake in Japan. Verhandlungen der Internationalen Vereinigung für Theoretische und Angewandte Limnologie, 28: 1409-1414. 